\title{
ISOLASI PROTEIN DAN PRODUKSI KONSENTRAT PROTEIN DAUN (KPD) SEBAGAI SUPLEMEN PAKAN TERNAK
}

\author{
Yatno, Suparjo dan Rasmi Murni \\ Program Studi Peternakan Fakultas Peternakan Universitas Jambi \\ Email : yatno@unja.ac.id.
}

\begin{abstract}
The research aim to determine the effect of extraction using various combination of $\mathrm{pH}$ alkaline-acid to protein and amino acid content of Lamtoro Protein Concentrate Leaf (LPCL). Completely Randomized Design (CRD) with 3 treatments and 5 replications. The Lamtoro Leaf Meal (LLM) (50 gram) was blended in $\mathrm{NaOH}$ (200 ml) for 15 menit and centrifuged to separate the supernatant from extracted LLM. The extracted LLM was re-extracted with buffer acetat $\mathrm{pH}$ 4,6 and sentrifuged again to separate supernantant from extracted LLM. Both supernatant from $\mathrm{NaOH}$ and buffera acetat $\mathrm{pH}$ 4,6 extraction were mixed and precipitated with buffer phospat until isoelectric point. The treatments were tested consisted of extracted with $\mathrm{NaOH} \mathrm{pH} \mathrm{8,}$ $\mathrm{NaOH} \mathrm{pH} 9$ and $\mathrm{NaOH}$ pH 10. The parameters measured; isoelectric point at precipited, crude protein, total amino acid (TAA), total essential amino acid (TEAA) and individual amino acid. The results showed that the precipited obtained isoelectric point $\mathrm{pH} 7$ was 2.66; 1.03 and 2.58 gram at the extraction treatments using $\mathrm{NaOH}$ at $\mathrm{pH} 8,9$ and 10, respectively. LPCL extracted using $\mathrm{NaOH}$ at $\mathrm{pH} 9$ and 10 contained a high crude protein of 54.82 and $52.60 \%$ higher than the extraction using $\mathrm{NaOH}$ at $\mathrm{pH} 8$ of $46.98 \%$. The total amount of amino acid and essential amino acid (AAE) of LPCL were highest in treatment using $\mathrm{NaOH}$ at $\mathrm{pH} 10$ of 26,$58 ; 13.31 \%$, respectively. Combination extraction LLM using $\mathrm{pH}$ buffer 10 followed by re-extract using acetate buffer $\mathrm{pH}$ 4,6 contains crude protein and good essential amino acid, especially leucine. Conclution of the research that the combination extraction using $\mathrm{NaOH}$ at $\mathrm{pH} 10$ and followed by re-extract using acetate buffer at $\mathrm{pH} 4.6$ is the best treatment contain crude protein and essential amino acid at LPCL.
\end{abstract}

Keywords : Crude protein, essential amico acid, extraction.

\section{PENDAHULUAN}

Harga ransum komersil di Indonesia dirasa cukup mahal, hal ini disebabkan penggunaan beberapa komponen pakan terutama sumber protein sebagian besar masih import, disamping juga menguras devisa negara. Disisi lain keberadaan pakan sumber protein di Indonesia cukup banyak baik yang berupa limbah agroindustri seperti bungkil inti sawit maupun tanaman lain seperti daun lamtoro, kaliandra, daun ubi dan lain-lain.

Beberapa hasil penelitian menunjukkan bahwa kandungan protein bungkil inti sawit dapat ditingkatkan proteinnya 3 kali lebih besar melalui ekstraksi kombinasi fisikokimia menjadi konsentrat protein (16 vs 46,5\%) (Yatno, 2009 dan Yatno et al., 2015). Lebih lanjut Tripathi et al., (2014) melaporkan pembuatan konsentrat protein dari daun Girardinia heterophylla mampu meningkatkan kandungan proteinnya menjadi 45,75\%/100 gram. Penelitian lain melaporkan bahwa pembuatan konsentrat protein dari daun paku air (Azolla africana Desv) mampu meningkatkan protein 3 kali lebih tinggi dari bahan awal yaitu dari $28,10 \%$ menjadi $71,30 \%$ dan daun kiambang (Spirodela polyrrhiza L. Schleiden) dari
25.00\% menjadi 64.60\% (Fasakin, 1999). Protein daun lamtoro dengan ekstraksi menggunakan buffer asetat pada $\mathrm{pH}$ 4,6 dapat meningkat dari 24,2\% menjadi 25,31\% (Yatno et al., 2016), sedangkan ektraksi protein dari daun kaliandra menggunakan buffer asetat $\mathrm{pH}$ 5,2 dapat meningkatkan protein dari 22\% menjadi 30,45\% (Yatno et al., 2016). Hasil yang diperoleh pada penelitian tersebut dirasa masih belum optimal dalam menghasilkan protein, asam amino maupun rendemennya, kuat dugaan karena hanya menggunakan buffer asetat dalam ekstraksinya, sehingga besar kemungkinan yang bisa larut hanya protein yang bersifat asam, sedangkan sebagian protein yang lain masih tertinggal di dalam padatan. Oleh karena itu, pada penelitian ini dilakukan ekstraksi bertingkat dengan menggunakan larutan basa $(\mathrm{NaOH})$ pada ekstraksi pertama dan padatan yang dihasilkan akan di ekstrak kembali (re-ekstrak) menggunakan buffer asetat, sehingga ekstrak I dan ekstrak II yang dihasilkan akan digabung dan bisa diambil proteinnya dengan metode pengendapan (precipitation) berdasarkan $\mathrm{pH}$ isoleketrik (pI). Padatan yang dihasilkan selanjutnya di sebut dengan Konsentrat Protein Daun (KPD). Dengan demikian diharapkan akan menghasilkan kandungan protein, 
asam amino dan pada akhirnya dapat dijadikan sebagai suplemen pakan ternak alternatif.

Penelitian ini bertujuan untuk mengetahui; 1 . $\mathrm{pH}$ isoelektrik protein dan $\mathrm{pH}$ yang tepat dalam mengisolasi protein dan memproduksi Konsentrat Protein Daun (KPD) dan 2. pengaruh perlakuan berbagai larutan $\mathrm{NaOH}$ yang dikombinasikan dengan buffer asetat terhadap kandungan protein dan asam amino . KPD Lamtoro

\section{MATERI DAN METODE}

Penelitian ini dilaksanakan di Laboratorium Dasar dan Terpadu, Laboratorium Peternakan, dan Laboratorium Instrumentasi dan Tugas Akhir Fakultas Sains dan Teknologi, Fakultas Peternakan Universitas Jambi, serta analisis asam amino di Laboratorium Kimia Terpadu Institut Pertanian Bogor.

Bahan yang digunakan dalam penelitian ini adalah daun lamtoro yang diperoleh dari lingkungan Fapet Farm Universitas Jambi. Bahan kimia yang digunakan adalah asam asetat, natrium fosfat, garam asetat, $\mathrm{NaOH}, \mathrm{HCl}$, asam sulfat, katalis $\mathrm{Na}_{2} \mathrm{SO}_{4}$ - $\mathrm{HGO}$, indikator metil merah $0,1 \%$, indikator bromcresol green $0,2 \%$, alkohol, buffer kalium borat, pereaksi ortoftalaldehida, metanol, merkaptoetanol, larutan brij 30\%, dan aquabides.

Alat yang digunakan pada penelitian ini adalah gelas beker $500 \mathrm{~mL}$, neraca analitik, batang pengaduk, Sentrifug Hitachi CR 21GT4, Mortar, Autoclave Temp And Time Control System Wisd, Magnetic Stirer, pH Meter BT-6oo, Hot Box Oven Size 2, tabung reaksi, corong kaca, kertas saring, gelas beker 250 $\mathrm{mL}$, inkubator, freeze dryer, kertas saring milipore, botol gelap, pipet tetes, erlenmeyer, aluminium foil, labu destruksi, alat destilasi, buret, statif dan HPLC.

Penelitian ini dilaksanakan dalam beberapa langkah yang saling terkait yaitu; tahap persiapan, tahap ekstraksi, menentukan $\mathrm{pH}$ isoelektrik, produksi KPD, analisis protein, dan analisis asam amino. Pertama yang dilakukan pengumpulan bahan baku yaitu daun lamtoro. Daun yang dipilih adalah daun yang muda, dikumpulkan, disortir, dibersihkan dari kotoran serta dipisahkan dari tangkai, dikeringanginkan sampai layu selama satu malam, dan ditimbang.

\section{Ekstraksi (Modifikasi Metode Yatno, 2009)}

Ekstraksi menggunakan $\mathrm{NaOH}$ o, $5 \mathrm{~N} \mathrm{pH} \mathrm{8,0;} \mathrm{pH}$ 9,0; $\mathrm{pH}$ 10,0; dan buffer asetat $\mathrm{pH} 4,0$, dilakukan sebagai berikut :

1. Daun lamtoro yang telah menjadi tepung sebanyak 100 gram dan $400 \mathrm{~mL} \mathrm{NaOH}$ (sesuai perlakuan) digiling dengan blender agar tercampur rata dan berbentuk pasta

2. Sampel disentrifugasi dengan kecepatan $4500 \mathrm{rpm}$ selama 15 menit untuk memisahkan padatan dan supernatan, sehingga diperoleh Supernatant I.

3. Padatan dilakukan re-ekstrak menggunakan 400 $\mathrm{mL}$ buffer asetat $\mathrm{pH}$ 4,o kemudian dilakukan dengan cara sama seperti yang sebelumnya hingga didapatkan Supernatan II.

4. Supernatan I dan II yang dihasilkan dicampur, lalu diambil $135 \mathrm{~mL}$ untuk diendapkan dengan buffer fosfat pada titik isoelektrik. Sisa residu dan filtrat disimpan di dalam lemari pendingin.

\section{Penentuan Titik Isoelektrik}

Penentuan titik isoelektrik (pI) dilakukan dengan cara mengambil $15 \mathrm{~mL}$ supernatan daun lamtoro gung dan masing-masing dimasukkan kedalam erlenmeyer. Larutan ekstrak diukur pH awalnya kemudian diatur $\mathrm{pH}-n y a$ mulai 3 sampai dengan $\mathrm{pH}$ 8 dengan cara menambahkan buffer fosfat sedikit demi sedikit hingga pH mencapai 3, 4, 5, 6, 7 dan 8 (dilakukan dengan 3 kali pengulangan). Selanjutnya di inkubasi selama 12 jam pada suhu dingin. Sampel disentrifugasi pada kecepatan 4700 rpm selama 30 menit. Endapan yang diperoleh dipisahkan dari filtrat dan dikeringkan dengan menggunakan oven pada suhu $40^{\circ} \mathrm{C}$ kemudian ditimbang. Jumlah endapan yang paling tinggi merupakan indikator $\mathrm{pH}$ pada titik isoelektrik dan dipakai sebagai dasar dalam produksi KPD lamtoro.

\section{Produksi KPD Lamtoro}

Sisa filtrat yang disimpan dilemari es diambil dan diukur $\mathrm{pH}$ awal. Kemudian diendapkan dengan buffer fosfat pada titik isoelektrik (sesuai langkah sebelumnya) dan disentrifugasi pada kecepatan 4700 rpm selama 15 menit kemudian diambil endapannya. Endapan tersebut dikeringkan dengan menggunakan oven pada suhu $40^{\circ} \mathrm{C}$ untuk selanjutnya dianalisis kandungan protein dan asam aminonya. Endapan tersebut selanjutnya disebut dengan KPD Lamtoro. Secara lengkap proses isolasi dan produksi Konsentrat Protein Daun disajikan pada Gambar 1.

\section{Analisis Protein Kasar (Metode AOAC, 1980)}

Metode analisis yang digunakan adalah menggunakan metode Kjeldahl. Disiapkan 0,25 gr sampel dengan teliti dan masukkan kedalam labu destruksi. Ditambahkan $5 \mathrm{~mL} \mathrm{H}_{2} \mathrm{SO}_{4} 98 \%$ dan 0,2 gram katalis campuran $\left(\mathrm{CuSO}_{4}\right.$ dan $\mathrm{Na}_{2} \mathrm{SO}_{4} 1$ : 20). Larutan dipanaskan dalam lemari asam dan diperhatikan proses destruksi selama pemanasan agar tidak meluap.Destruksi dihentikan bila larutan sudah menjadi hijau terang atau jernih, lalu dinginkan dalam lemari asam.

Larutan dimasukkan ke dalam labu destilasi dan diencerkan dengan $90 \mathrm{~mL}$ akuades. Beberapa buah 
batu didih dimasukkan. Destilat ditampung dalam labu erlenmeyer yang berisi $25 \mathrm{~mL} \mathrm{H}_{2} \mathrm{SO}_{4} \mathrm{O}, 3 \mathrm{~N}$ dan 2 tetes indikator campuran metil merah (o,1\% dalam etanol) dan bromkresol hijau (o,2\% dalam alkohol) dan kemudian dihubungkan ke sistem destilasi, yakni bagian ujung pipa ke dalam larutan erlenmeyer. Perlahanlahan larutan dituangkan (melalui dinding labu) $20 \mathrm{~mL}$ $\mathrm{NaOH} 40 \%$ w/v ke dalam labu dan segera hubungkan dengan destilator.Destilasi dilakukan hingga $\mathrm{N}$ dari cairan tersebut tertangkap oleh $\mathrm{H}_{2} \mathrm{SO}_{4}$ yang ada dalam erlenmeyer (2/3 dari cairan yang ada pada labu destilasi menguap atau terjadi letupan-letupan kecil atau erlenmeyer mencapai volume $100 \mathrm{~mL}$ ).

Labu erlenmeyer berisi sulingan diambil dan dititrasi kembali dengan $\mathrm{NaOH} 0,3 \mathrm{~N}$. Perubahan dari warna merah muda ke biru menandakan titik akhir titrasi. Kemudian hasilnya dibandingkan dengan titrasi blanko.Untuk menghitung kadar protein yang diperoleh, digunakan persamaan:

$\%$ protein $=\frac{(\text { blanko-sampel) } \times N \text { NaOHx } 0,014 \times 6,25 \times 100 \%}{\text { massa sampel }}$

\section{Analisis Asam Amino (Modifikasi Metode} AOAC, 1999)

Komposisi asam amino ditentukan dengan menggunakan HPLC. Sebelum digunakan, perangkat HPLC harus dibilas dulu dengan efluen yang akan digunakan selama 2-3 jam. Begitu pula syring yang akan digunakan dibilas dengan akuades. Analisis asam amino dengan menggunakan HPLC terdiri atas 4 tahap, yaitu: (1) tahap pembuatan hidrolisat protein; (2) tahap pengeringan; (3) tahap derivatisasi; (4) tahap injeksi serta analisis asam amino.

\section{Rancangan Penelitian dan Analisis Data}

Rancangan percobaan yang akan digunakan dalam penelitian ini adalah Rancangan Acak Lengkap (RAL) menggunakan 3 perlakuan, masing-masing diulang sebanyak 5 kali untuk ekstraksi basa. Perlakuan yang diterapkan adalah sebagai berikut:

1). Ekstraksi menggunakan $\mathrm{NaOH} \mathrm{pH} 8$

2). Ekstraksi menggunakan $\mathrm{NaOH}$ pH 9

3). Ekstraksi menggunakan $\mathrm{NaOH}$ pH 10

\section{Peubah yang Diamati}

Peubah yang diamati pada penelitian ini meliputi:

1. Titik isoelektrik pengendapan protein

2. Kadar protein dari KPD Lamtoro diperoleh dengan menghitung persentase nitrogen yang mewakili gugus amina dari asam amino yang terikat menjadi protein.

3. Kandungan asam amino dari KPD Lamtoro dianalisis menggunakan HPLC.

Data yang diperoleh dilakukan analisis ragam
(ANOVA). Jika terjadi perbedaan nyata dilanjutkan dengan uji jarak Duncan.

\section{HASIL DAN PEMBAHASAN}

\section{Penentuan Titik Isoelektrik (pI)}

Titik isoelektrik merupakan kondisi $\mathrm{pH}$ yang menghasilkan endapan tertinggi dari proses pengendapan protein. Jumlah endapan KPD Lamtoro pada saat penentuan titik isoelektrik tercantum pada Tabel 1.

Tabel 1. Jumlah Endapan pada Saat Penentuan pl KPD Lamtoro pada Berbagai pH (gram)

\begin{tabular}{cccc}
\hline & \multicolumn{3}{c}{ Perlakuan Ekstraksi } \\
\cline { 2 - 4 } & $\mathrm{NaOH} \mathrm{pH} 8$ & $\mathrm{NaOH} \mathrm{pH} \mathrm{9}$ & $\mathrm{NaOH} \mathrm{pH} \mathrm{10}$ \\
\hline 3 & 0,05 & 0,09 & 0,06 \\
4 & 0,01 & 0,04 & 0,06 \\
5 & 0,06 & 0,06 & 0,09 \\
6 & 0,57 & 0,79 & 0,31 \\
7 & 2,66 & $\mathbf{1 , 0 3}$ & $\mathbf{2 , 5 8}$ \\
8 & 0,84 & 0,62 & 0,99 \\
\hline
\end{tabular}

Hasil penelitian menunjukkan bahwa endapan tertinggi dari setiap perlakuan diperoleh pada saat pengaturan $\mathrm{pH} 7$ sebanyak 2,66 gram pada perlakuan ekstraksi $\mathrm{pH} 8$ dan 1,03 gram pada perlakuan ekstraksi $\mathrm{pH} 9$ serta 2,58 gram pada perlakuan ekstraksi $\mathrm{pH}$ 10. Hal ini sejalan dengan beberapa teori bahwa pengendapan protein dapat dilakukan dengan pengaturan $\mathrm{pH}$ dan suhu serta penggunaan pelarut organik. Protein akan menjadi bermuatan negatif atau positif jika $\mathrm{pH}$ medium dinaikkan di atas atau diturunkan dibawah titik isoelektriknya. Pada $\mathrm{pH}$ yang rendah terjadinya penambahan proton dari gugus amida, sehingga bermuatan positif, sedangkan pada $\mathrm{pH}$ yang tinggi mempunyai muatan negatif, karena gugus karboksil pada protein backbone kehilangan proton. Pada titik isoelektrik, protein tidak mempunyai muatan dan solubilitasnya rendah karena protein tidak mampu berinteraksi dengan medium dan kemudian mengendap ke dalam larutan (Scope 1982, Harris \& Angal 1989). Dengan demikian merubah pH dari larutan yang mengandung protein akan dapat menyebabkan pengendapan sebagian protein.

Dengan demikian untuk proses selanjutnya dalam menghasilkan atau memproduksi KPD Lamtoro dilakukan dengan mengekstrak terlebih dahulu pada kondisi basa dan mengendapkan ekstrak tersebut pada $\mathrm{pH} 7$, sehingga akan diperoleh hasil produksi konsentrat protein secara optimal.

\section{Kandungan Protein dan Asam Amino KPD Lamtoro (\%)}

Kriteria utama untuk melihat kualitas konsentrat protein suatu produk adalah dengan cara menentukan 


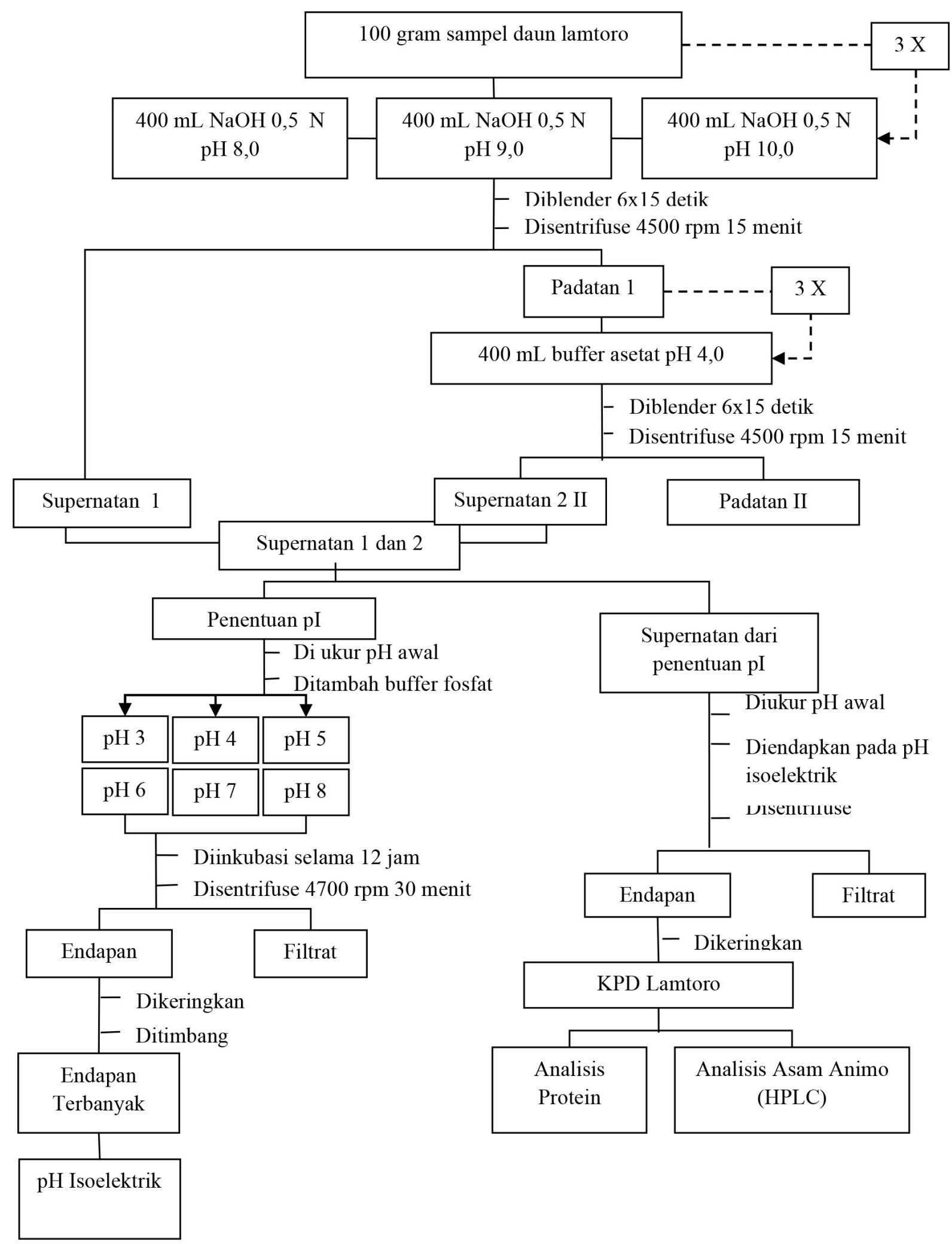

Gambar 1. Proses isolasi protein dan produksi KPD Lamtoro

kandungan protein kasar dari produk tersebut. Selanjutnya kualitas protein yang ada pada produk tersebut sangat ditentukan oleh keberadaan asam amino dari protein tersebut. Rataan hasil analisis protein dan asam amino KPD Lamtoro tercantum pada Tabel 2.
Hasil penelitian menunjukkan bahwa KPD Lamtoro hasil ekstraksi menggunakan $\mathrm{NaOH}$ pada pH 9 dan 10 mengandung protein kasar cukup tinggi masing-masing sebesar 54,82 dan 52,60\% lebih tinggi dibanding dengan ekstraksi menggunakan $\mathrm{NaOH}$ pada pH 8 sebesar 46,98\%. Jika dilihat kandungan protein 
Tabel 2. Rataan Kandungan Protein Kasar dan Asam Amino pada KPD Lamtoro (\%)

\begin{tabular}{ccccc}
\hline \multirow{2}{*}{ Perlakuan Ekstraksi } & \multicolumn{4}{c}{ Peubah } \\
\cline { 2 - 5 } & Protein Kasar & Total Asam Amino & Total Asam Amino Esensial & Total Asam Amino Non Esensial \\
\hline $\mathrm{NaOH} \mathrm{pH} 8$ & $46,98^{\mathrm{b}} \pm 5,92$ & $21,77^{\mathrm{c}} \pm 0,58$ & $9,78^{\mathrm{c}} \pm 0,52$ & $11,99^{\mathrm{c}} \pm 0,07$ \\
$\mathrm{NaOH} \mathrm{pH} 9$ & $54,82^{\mathrm{a}} \pm 2,78$ & $25,12^{\mathrm{b}} \pm 0,27$ & $12,65^{\mathrm{b}} \pm 0,14$ & $12,47^{\mathrm{b}} \pm 0,14$ \\
$\mathrm{NaOH} \mathrm{pH} 10$ & $52,60 \mathrm{a} \pm 4,48$ & $26,58^{\mathrm{a}} \pm 0,31$ & $13,31^{\mathrm{a}} \pm 0,17$ & $13,26^{\mathrm{a}} \pm 0,14$ \\
\hline
\end{tabular}

kasar daun lamtoro sebesar $28,2 \%$, peningkatan protein ini cukup tinggi. Tripathi et al., (2014) melaporkan pembuatan konsentrat protein dari daun Girardinia heterophylla mampu meningkatkan kandungan proteinnya menjadi 45,75\%/10o gram. Penelitian lain melaporkan bahwa pembuatan konsentrat protein dari daun paku air (A. africana Desv) mampu meningkatkan protein 3 kali lebih tinggi dari bahan awal yaitu dari $28,10 \%$ menjadi $71,30 \%$ dan daun kiambang (Spirodela polyrrhiza L. Schleiden) dari $25.00 \%$ menjadi $64.60 \%$ (Fasakin, 1999). Protein daun lamtoro dengan ekstraksi menggunakan buffer asetat pada $\mathrm{pH}$ 4,6 dapat meningkat dari 24,2\% menjadi 25,31\% (Yatno et al., 2016), sedangkan ekstraksi protein dari daun kaliandra menggunakan buffer asetat $\mathrm{pH}$ 5,2 dapat meningkatkan protein dari 22\% menjadi 30,45\% (Yatno et al., 2016). Moure et al. (2001) melakukan ekstraksi dan isolasi protein dari biji Rosa rubiginosa menggunakan larutan akuades dan $\mathrm{NaCl}$ 0.5M pada suhu 30-60oC selama 90 menit. Langkah pertama sampel dicampur larutan akuades atau $\mathrm{NaCl}$ 0.5M pada suhu $350 \mathrm{C}$, pH 11 selama 90 menit, kemudian dilakukan penyaringan, filtrat yang diperoleh ditampung, kemudian residu ditambah lagi dengan larutan maupun waktu yang sama dengan sebelumnya, kemudian disaring lagi. Filtrat yang diperoleh dari kedua langkah tersebut diendapkan sebagai konsentrat protein.

Ramli et al. (2008) melaporkan bahwa isolasi protein dari BIS dengan ekstraksi menggunakan pelarut air: $\mathrm{NaOH} 0.05 \mathrm{~N}$ dan diendapkan dengan etanol 80\% (1:1) menghasilkan rendemen sebesar 3\%, kandungan protein kasar 42.92\%. Sedangkan pada metode ekstraksi yang sama namun di tingkatkan konsentrasi $\mathrm{NaOH}$ menjadi $1 \mathrm{~N}$ dan menggunakan bahan pengendap $\mathrm{HCl} 0.1 \mathrm{~N}$ pada titik isoelektrik $(\mathrm{pH}$ 4) menghasilkan rendemen sebesar $5.3 \%$, kandungan protein $53.17 \%$ dan protein recovery $20.27 \%$ (Yatno et al. 2008). Pembuatan konsentrat dari pollard menggunakan air dan $\mathrm{NaOH}$ mampu menghasilkan protein sebesar $35.10 \%$ (Haryati \& Tangendjaja 1993). Ordonez et al. (2001) melaporkan bahwa pembuatan konsentrat protein dari tepung kembang matahari dengan cara mengesktrak menggunakan $\mathrm{KOH}$ 0.5 $\mathrm{N}$ pada suhu $40^{\circ} \mathrm{C}$, pH awal 10.5 serta diendapkan dengan $\mathrm{H}_{2} \mathrm{PO}_{4} 0.5 \mathrm{~N}$ suhu $25^{\circ} \mathrm{C}$ pada pH 4.5 menghasilkan protein tertinggi $(71.50 \%)$ dibandingkan dengan $\mathrm{pH}$ lainnya $(2.5,3.5$ dan 5.5$)$ masing-masing sebesar 56.57, 60.15 dan 56.23\%.

Kandungan total asam amino dan asam amino esensial (AAE) maupun asam amino non esnsial (AANE) KPD Lamtoro yang tertinggi ada pada perlakuan yang menggunakan $\mathrm{NaOH}$ pada $\mathrm{pH} 10$ masing-masing sebesar 26,$58 ; 13,31$ dan $13,26 \%$. Jumlah total asam amino yang diperoleh dari penelitian ini hampir sama dibandingkan konsentrat tepung bunga matahari sebesar 29,95\% (Ordonez et al; 2001), namun lebih rendah dari konsentrat protein daun singkong sebesar 50,24\% (Fasuyi dan Aletor; 2005) dan konsentrat protein buah cashew sebesar 35.3\% (Aremu et al; 2007).

\section{Kandungan Asam Amino Esensial (AAE) dan Non Esensial (AANE) KPDL (\%)}

Kandungan setiap komponen AAE maupun AANE KPD Lamtoro tercantum pada Tabel 3. Seluruh perlakuan memperlihatkan bahwa AAE yang tertinggi adalah leusin sebesar 1,81; 2,46 dan 2,73\% masing KPD Lamtoro yang diekstraksi menggunakan $\mathrm{NaOH}$ pH 8, 9 dan 10, sedangkan asam amino esensial yang paling kecil kandungannya adalah metionin untuk semua perlakuan. Kandungan AANE yang paling besar adalah aspartat dan glutamat untuk seluruh produk KPD Lamtoro.

Tingginya kandungan AAE leusin pada penelitian ini sejalan dengan peneliti lain seperti Ordonez et al (2005) bahwa kandungan leusin konsentrat protein tepung bunga matahari sebesar $4,45 \%$ dan yang paling rendah adalah metionin sebesar $1,43 \%$, sedangkan konsentrat protein dari daun singkong masing-masing sebesar 9,56 dan 2,48\% (Fasuyi dan Aletor, 2005). Perbedaan kandungan asam amino yang diperoleh dari penelitian ini disamping dipengaruhi oleh bahan bakunya juga sangat mungkin dipengaruhi oleh proses pembuatan konsentrat tersebut.

Jika dibandingkan dengan konsentrat yang diperoleh dari hasil ekstraksi limbah industri seperti bungkil inti sawit, memiliki 3 buah AAE yang rendah antara lain metionin, histidin dan lisin masing-masing sebesar $0.24,0.27$ dan $0.35 \%$, sedangkanbungkil kedelai defisien terhadap asam amino metionin. Ekstraksi protein merupakan proses pemisahan atau pemindahan protein dari komponen lain pada suatu bahan yang bertujuan untuk mendapatkan protein sebanyak mungkin (Scope 1982), sehingga nantinya dapat memanfaatkan protein tersebut secara 
optimal khususnya sebagai suplemen pakan ternak. Proses ekstraksi merupakan tahap awal yang sangat menentukan untuk melakukan penelitian tentang protein.

Tabel 3. Kandungan AAE dan AANE KPD Lamtoro (\%)

\begin{tabular}{lccc}
\hline \multirow{2}{*}{ Asam Amino } & \multicolumn{3}{c}{ Perlakuan Ekstraksi } \\
\cline { 2 - 4 } Asam Amino Esensial : & $\mathrm{NaOH} \mathrm{pH} 8$ & $\mathrm{NaOH} \mathrm{pH} 9$ & $\mathrm{NaOH} \mathrm{pH} 10$ \\
Methionin & $0,37 \pm 0,002$ & $0,43 \pm 0,005$ & $0,49 \pm 0,01$ \\
Arginin & $1,47 \pm 0,01$ & $1,72 \pm 0,02$ & $1,84 \pm 0,02$ \\
Threonin & $1,12 \pm 0,01$ & $1,41 \pm 0,02$ & $1,54 \pm 0,02$ \\
Histidin & $0,50 \pm 0,003$ & $0,55 \pm 0,01$ & $0,55 \pm 0,01$ \\
Isoleusin & $1,40 \pm 0,01$ & $1,57 \pm 0,02$ & $1,60 \pm 0,02$ \\
Leusin & $1,81 \pm 0,01$ & $2,46 \pm 0,03$ & $2,73 \pm 0,03$ \\
Lisin & $0,48 \pm 0,47$ & $1,29 \pm 0,01$ & $1,29 \pm 0,01$ \\
Phenilalanin & $1,25 \pm 0,01$ & $1,50 \pm 0,02$ & $1,57 \pm 0,02$ \\
Valin & $1,37 \pm 0,01$ & $1,72 \pm 0,02$ & $1,71 \pm 0,04$ \\
Asam Amino Non Esensial: & & & \\
Aspartat & $3,84 \pm 0,02$ & $3,04 \pm 0,03$ & $3,35 \pm 0,04$ \\
Glutamin & $3,00 \pm 0,03$ & $3,81 \pm 0,04$ & $3,93 \pm 0,04$ \\
Serin & $1,09 \pm 0,01$ & $1,29 \pm 0,01$ & $1,35 \pm 0,01$ \\
Glisin & $1,31 \pm 0,01$ & $1,35 \pm 0,01$ & $1,44 \pm 0,02$ \\
Tirosin & $1,09 \pm 0,01$ & $1,14 \pm 0,01$ & $1,17 \pm 0,01$ \\
Alanin & $1,65 \pm 0,01$ & $1,84 \pm 0,02$ & $2,03 \pm 0,02$ \\
\hline
\end{tabular}

Berdasarkan hasil yang telah diperoleh bahwa ekstraksi kombinasi menggunakan $\mathrm{NaOH} \mathrm{pH} 10$ dilanjutkan dengan re-ekstrak menggunakan buffer asetat $\mathrm{pH}$ 4,6 mengandung protein kasar maupun asan amino esensial yang baik serta banyak mengandung asam amino esensial terutama leusin. Dengan demikian dari semua peubah maka isolasi dan produksi KPD menggunakan kombinasi ekstraksi menggunakan $\mathrm{NaOH} \mathrm{pH} 10$ dan dilanjutkan dengan re-ekstrak menggunakan buffer asetat pada pH 4,6 merupakan perlakuan terbaik.

\section{KESIMPULAN}

Berdasarkan hasil penelitian dapat disimpulkan sebagai berikut :

1. Titik isoelektrik pembuatan KPD Lamtoro yang diekstraksi menggunakan $\mathrm{NaOH}$ pH 8 sampai 10 dicapai pada $\mathrm{pH} 7$, karena pada $\mathrm{pH}$ tersebut dihasilkan endapan tertinggi dibanding $\mathrm{pH}$ lainnya

2. Ekstraksi tepung daun lamtoro menggunakan $\mathrm{NaOH}$ pada $\mathrm{pH} 10$ dan dilanjutkan dengan reekstrakasi menggunakan buffer asetat $\mathrm{pH}$ 4,6 menghasilkan KPD Lamtoro terbaik berdasarkan kandungan protein kasar, total asam amino dan asam amino esensial

3. KPD Lamtoro bisa dijadikan suplemen asam amino esensial leusin pada pakan.

\section{DAFTAR PUSTAKA}

Amoo, I. A., O. T. Adebayo, A. O. Oyeleye.2006. Chemical evaluation of winged beans (Psophocarous tetragonolabus), Pitanga Cherries (Eugenia uniflora) and Orchid Fruit (Orchid fruit myristica). African. .J food Agr.Nutr.Dvlpmnt. 2:1-12.

Association of Official Analytical Chemist. 2005. Official Method of Analysis of The Association of Official Analytical of Chemist.Association of Official Analytical Chemist, Inc:USA.

Dewi, N. Y. 2013. Penetapan Kadar dan Analisis Profil Protein dan Asam Amino Ekstrak Ampas Biji Jinten Hitam (Nigella sativa Linn.) dengan Metode SDS-Page dan KCKT. UIN Jakarta: Jakarta.

D'Mello, F and T. Acamovic. 1992. The Toxicity of Leucaena Leaf Meal for Poultry: A Critical Assesment of Recent Evidence Concerning The Mode of Action. Leucaena Research Reports Vol. 9 September 1998. Council of Agriculture, Nanhai Road, Taipei, Taiwan, Republic of China.p.97

Fasakin E. A. 1999. Nutrient quality of leaf protein concentrates produced from water fern (Azolla africana Desv) and duckweed (Spirodela polyrrhiza L Schleiden). Biores Technol 69: 185-187.

Fasuyi O. A, V. A. Aletor. 2005. Varietal composition and functional properties of cassava (Manihot esculenta. Cranzt) leaf meal and leaf protein concentrate. Pak J Nutr 4: 43-49.

Ordonez C, M. G. Asenjo, C. Benitez, Gonzales JL. 2001. Obtaining a protein concentrate from integral defatted sunflower flour. Biores Technol 78: $187-190$

Ramli N, Yatno, A. D. Hasjmy, Sumiati, Rismawati, R. Estiana. 2008. Evaluasi sifat fisiko-kimia dan nilai energi metabolis konsentrat protein bungkil inti sawit pada broiler. J Ilmu Ternak dan Veteriner 13:249-255.

Yatno, N. Ramli , P. Hardjosworo, A. Setiyono dan T. Purwadaria. 2008. Chemical characteristics and biological value of protein concentrate from palm kernel meal using physical and chemical extraction. Media Peternakan. 31 (3): 178-185.

Yatno. 2009. Isolasi Protein Bungkil Inti Sawit dan Kajian Nilai Biologinya Sebagai Alternatif Bungkil Kedelai Pada Puyuh [Disertasi]. Sekolah Pascasarjana, Institut Pertanian Bogor: Bogor.

Yatno, Adrizal, R. Murni, Nelson, M. Latief dan Fitriyah. 2015. Pengaruh lama waktu ekstraksi dan konsentrasi bahan pengendap terhadap jumlah rendemen dan protein recovery konsentrat protein bungkil inti sawit. Proseding Seminar 
Nasional LPPM Universitas Jambi.

Yatno, Adrizal, R. Murni, S. Fakhri, Suparjo dan Nelson. 2016. Ekstraksi dan isolasi protein daun lamtoro sebagai upaya penyediaan suplemen pakan masa depan. Laporan Penelitian, Fakultas Peternakan Universitas Jambi.

Yatno, Nelson dan R. Murni, 2016. Isolasi protein dan analisis asam amino konsentrat protein daun kaliandra sebagai upaya penyediaan suplemen pakan ternak. Laporan Penelitian, Fakultas Peternakan Universitas Jambi. 